\title{
The Imperative Progress Versus the Ethics of Moderation: Future Expectations in the Society of Knowledge
}

\begin{abstract}
Arthur Wagner
ABSTRACT: The 20th and 21st century are characterized by a strong urge for progress in the field of technology, knowledge, communication and business. These structural changes patronized the emergence of a knowledge society, where knowledge is the basis of economic and social growth. The other side of progress is characterized by ambivalent effects. While the idea of progress is based on development and crossing the institutionalized limits, the ethics of responsibility starting from respecting the limits and the temperature, following the aim of sustainability. Hans Jonas sets with his principle the responsibility of a distinctive scale both in dealing with the present and with the future. Without an interdisciplinary exchange, the ethics of moderation proves in its action to be guidance, but only limited. The wider actual acceptance of "sustainability" reveals its chances towards becoming a global ethos.

KEY WORDS: imperative progress, knowledge society, ethic, moderation, responsibility, future.
\end{abstract}

The Society of Knowledge and the Imperative Progress

372 years ago, René Descart wrote the following in his third

3 meditation Principia Philosophiae:

Perhaps all the perfections that I attribute to God preserve in me some kind of capability. ... I am doing this already in 
my experience, and so my knowledge is gradually growing. And I do not see what stands in the way to grow more and more to infinity and why am I not able to achieve all the other perfections of God, with such increased knowledge?" (Descartes 1986, 48)

Had Descartes predicted that the instinct of knowledge, which would be developed endlessly in order to reach a divine perfection, is truly as innocent as it looks? Is this demand just a scientific curiosity as those of the Pythagoreans or of Johannes Kepler, which should lead to the edification of the harmony of laws of nature? The instinct ok knowledge tends towards power - as Bacon and Freud noticed. (see Freud 1940; Bacon 1613). Man wants to finally overcome his dependence; he wants to no longer belong to nature, but instead, he wants nature to belong to him.

The 20 th century was characterized by an increasing acceleration and expansion of transport and communication, of the scientific system and by an increase of the investments in research and development as trends in social change. (see Bell 1973; Stehr 1994). The result was the change in the perception of time, destruction of distances, creation of national markets, expansion of national and international contacts, globalization, horizons' enlargement, both positive and negative, and the standardization of timekeeping. A successful social movement was developed, where the concepts of religion, thinking and action were questioned. (see Beck 2007, 392).

In addition, there were recorded the incipient radical changes in the working environment and-parallel with this-the social forms of organization by information technologies. (see Castells 1996). So, the discussion was focused predominantly on the advancement of information and knowledge society in the first wave in the $1970 \mathrm{~s}^{1}$ (see Böhme/Stear 1986; Kreibich 1986; Stehr 1994; Schmiede in Gamm u.a. 2004, 38) and in this way it attracted attention on the academic activity, of the experts circles at the universities and companies level. A qualitative trend became apparent. Since the mid-1990s, the second wave has expanded this focus. (see Drucker 1994a and Drucker 1994b, Stehr 1994, Knorr-Cetina 1998). 
This influenced both the construction of scientific societies and their development, reinforced by an altered character of science itself. Thus, knowledge became in the postindustrial society a basic structural politic dimension, an essential principle and a progress fundament. The development of the knowledge society is due to the structural changes of the economy, which increasingly supports the economic capital on knowledge. If the industrial society is based on property and labor, knowledge enters into the scientific society as a new principle. (Stehr /Adolf 2015, 220).

Nobody would deny today that we are living in a knowledge society. The rapid change, the increasing knowledge of the people, simultaneously forces to the ongoing adjustment, to changes in qualification, to lifelong learning, openness and flexibility. As a guiding concept, the term information and knowledge society receives the promise of an era where, during its transgression, the man gets closer to the ideal of self-fulfillment. This contrasts with the pessimistic conceptions around the terms: risk, uncertainty, declining authority of the experts, assembling presumption of an unjustified and illegitimate authority. (Beck 1986; Beck et.al. 1994)

Furthermore, the explosion of media and knowledge is hiding with all its communication possibilities, by intellectual and cognitive overload, new exclusions in the form of access restrictions, commercialization of knowledge or confusion, even with the risk of reality loss. (Ulfing 2003,35). This is because the modernity of the 21st century is supported by the trend of attainment the "progress until the end." Due to faster and faster developments and to a more accurate time measurement, modernity is a "culture of time". The time destroyed the space and the modern man breaks it as well, "carried away by changes, being devoured by acceleration."(Schmid 1998a, 98; 1993, 31ff).

In this context it was discussed about a "culture of crises" which has reached the peak of the development taking into consideration both the advantages and the problems that came along the way. (Schmid 1998, 101). The hope and improvement of life quality ${ }^{2}$ on the one hand and fears on the other hand will be the sacrificed for the own creation of technique and science. 
The proliferation of scientific knowledge leads to the modernization of the society, but it also brings along uncertainty. This ambivalence represents a challenge for the future. This is because the developments of modern societies bring along certain fragility to the contemporary knowledge society due to their complexity. This process is far from being complete. (Stehr / Adolf 2015, 220)

\section{The Ethics of Moderation and Responsibility}

The ethics of responsibility try to offer as answer guidance to the new society structure, as the ethics an ethic of moderation. Today, ethics must be strengthen by having discussed more conflicts, based on a pluralist approach. (Huber 2013, 9). This is remarked among other things even in the great demand of ethics committees, convened on professional, religious, economic and political level.

The idea of progress is based on crossing over the limits of growth, while the ethics of responsibility is based on minding these limits and moderation, for the purpose of sustainability. It evaluates the idea of progress - which is based on growth - the setting of limits as a loss, while the ethics of responsibility evaluates this positively. (Stückelberger 1997, 342-343).

The modern ethics of responsibility is closely linked to the ethics of the mass, which is justified both philosophically and theologically. Hereinafter, the selected philosophical perspectives of Dieter Birnbacher, Hans Jonas, Georg Picht and Wilhelm Schmid will be explained.

The German philosopher Birnbacher founded his ethics anthropocentrically and started with the question of the use and preservation of nature and people. The utilitarian principle-"the greatest happiness for the greatest number of people"-is further expanded to include the responsibility for the future generations. (Birnbacher 1988 cited in: Stückelberger 1997, 108)

Birnbacher starts from the egoist's premise and then of the rational collectivism and reaches in the end at the rational universalist, which is capable of taking decisions oriented towards benefit, without taking into consideration his own preferences. 
(Birnbacher 1988, 57) Even if later on Birnbacher admits that this is an ideal case, there still remain some open questions regarding the acquisition of motivation for a responsible behavior.

The German Jewish philosopher Hans Jonas sustains less than others the issue of the responsibility dealings with the progress. In his work The Principle of Responsibility (1979), he replies imperative to the progress with an attitude of restraint. (Stückelberger 1997, 210)

Jonas explains his concept of responsibility based on the advancing technology (Huber 2013, 119) and sees the danger in the fact that the modern technologies-which originally served for the society`s welfare-have changed their purpose. Even if technologies are necessary to sustain life, they also endanger the natural resources of life preservation for the future. On top of this, there is the fact that technology and the exact science of nature have unilaterally promoted the superiority of the human nature. (Jonas 1987, 40)

At the same time, W. E. Müller sees in the nowadays technology no longer a mean to achieve a certain goal, but the compulsive urge for development, for satisfying the needs and at the same time, for creating new ones. (Müller 1988, 17)

By becoming aware of the future effects, Jonas linked the knowledge to the future prospect, in order to move from motivation to action.

By this connection with the feeling, which gives an answer for the future human condition, contributes such a preview to humanization of scientific and technical knowledge. This has to be merged in the future with people's knowledge when extrapolating. (Jonas/ Mieth 1983, 21)

Jonas' Responsibility leads to moderation, not only in the consumer's sector or in the acquisition of power, but also in the field of "human excellence." (Jonas 1985, 70) His ethics of responsibility is a request for pause and understanding. (Stückelberger 1997, 212)

The philosopher Georg Picht has also developed a "term of measure" (Picht in Eisenbart 1979), inspired by the Greek 
philosophy, as a draft of a cosmic order. He sees in the measure exceeding, the cause of the downfall of companies as well as of individuals. Growth does not mean for him to reach a maximum, but to move in the range of a "relative optimum." (Picht in Eisenbart, 1979 cited in Stückelberger 1997, 214)

Picht sees in responsibility-a term constituted from a double significance, namely the responsibility "towards something/ somebody" and the responsibility "for something/somebody"-a important theme for the present. (Picht 1969, 7. 320)

In the same direction, the German representative of the art of living philosophy, Wilhelm Schmid, discusses about the necessity of creating a new ethics "considering the exuberant possibilities of modernity" (Schmid 1998, 100; see Höffe 1993) and its large foreign destination potential.

The concept of freedom was particularly understood in the modern age as a liberation from bondage. On the other hand, the released individual cannot live without ties. His approach is to have a balance-as an exciting harmony in tension between freedom and commitment, progress and equality, self determination and heteronomy, community and self, between the rational pragmatism and romantic idealism. At the same time, the measure of the center is not clearly defined, but it represents a vacillation between too much and too little. (Schmid 2004, 266ff.)

\section{An Outlook: Future Prospects}

The findings of the future research point out to a stronger future expression of the service society, where a transfer of goods would be held for the export of knowledge. This means that the know-how is sold as a service. This is because the capital of the future service society is based on "research and development, planning and design, marketing and distribution." (Opaschowski 2013, 84)

"Who stops learning in the future-can stop living as well." (Opaschowski 2013, 489) Knowledge acquisition, horizons' broadening, formal and also informal education should gain more 
importance in the future, considering the voluntary experiential learning. (Ibid.; see Horx 2002, 154-155)

It is clear that the Western European future moves in the area of the information society and economic and social sustainability, between the urge for progress and coming back. That is why it is important to develop actionable ways and scenarios that stand between these two poles. (Steinmüller and others 2000, 51)

From this background on it emerged the question about the opportunities and borders of an ethics of responsibility, respectively of moderation in the design of a sustainable future concept. Only the criticism of the growth and progress delusion is not enough; instead, it is recommended to have a strategy of the value balance rather than one-sided value maximization. (Stückelberger 2013, 342) The potential of the new one must not be lost from sight.

The different approaches make it clear that the drafts of such an ethics should consider both economic and political structures. Since the aspect of human development and of growth is also vital, this should be considered sufficient, because the connection between the environment and growth and the various conflicts of interest and survival or development needs are not adequate in many ethical approaches. (Stückelberger 2013, 225)

In this context, space should be also created to the desire for positive border crossings. (see Schärli 1992, 109ff.). At the same time, there appears the need to make the value of "moderation" attractive and with positive content, in terms of a profit. In case of a collective consumer behavior, the possible therapeutic approaches should be taken into consideration. (Stückelberger 2013, 343) Only if new economic possibilities are created and if resources are enabled, individuals and institutions can gain benefits from the social change. (Pinquart/Silbereisen in Hasselhorn/Schneider 2007, 451)

Even if the ethics of moderation can offer valuable guidance in the current value conflicts, their contribution proved to be limited. Without any interdisciplinary exchange, their effect often sums up to a decelerating appeal. (Stückelberger 2013, 144) However, the increasingly broad acceptance of the value of sustainability shows that there is a chance to establish a global ethics of moderation and of responsibility and this to be accepted as a common value basis. 
(Either from responsibly ethical or egoistic-utilitarian reasons) (Ibid. 225)

Because with the knowledge of the ethics of moderation in the background, there is a possibility that modernity does not stop, but expands the category of sustainability. (see Brenner 1996, 134) In the future, an "ethics of sustainability" is possible to be developed from different ethical suppositions about responsibility and temperance.

Binde highlights in this context the necessity of integrating the future in the present decisions. The future requires an active attitude of the individuals, and also the questioning of flexibility as principle and the emphasis on responsibility and caution in the field of cultural heritage. (Binde 2007, 320ff.)

Opaschowski (2013) sees the necessity of creating a comprehensive and holistic prosperity concept, that is human and not economically oriented. Because the responsibility for the present is not sufficient, but it requires a "forward-thinking responsibility" for the next generations, in the opinion of Hans Jonas: "Act in such a way for your actions to be compatible with the permanency of real human life on earth." (Jonas 1979, 36)

Since in the future is predicting a progressive knowledge explosion in connection with the acceleration processes, power and responsibility as well as knowledge and foreknowledge go hand in hand. (Opaschowski 2013, 724; see Horx 2002, 154-155) At this point, the challenge of a multidisciplinary research is added, allowing the further insight in the context conditions of the knowledge society, risk factors and resource optimization. Thus, there are repercussions of modern knowledge society both for the ethical and political-educational challenge of the 21st century.

NOTES

${ }^{1}$ Final report of the Federal Ministry for Education, Science, Research and Technology, a contract in which a thousand of experts were involved: "Knowledge is always central as a precondition for the agreement on common objectives, for securing the scientific development, as well as for social actions and social position of individuals" (cited from ZEIT v.16.7.98:31 in Wingens 1999) 
2 This gives the individuals the possibility to live life after their own ideas. Theoretical descriptions of the society such as multi-option society (Gross 1994), experience-driven society (Schulze 1992) or information society (Castells 1996) are attempts for a differentiated knowledge or service society with the perspective of the subjective possibilities to participate in the structural changes.

\section{BIBLIOGRAPHY}

Bacon, Francis Sir. 1613. The Essaies of Sr. Francis Bacon. His religious meditations. Places of perswasion and disswasion. Seene and allowed. 1561-1626. London: I. Iaggard.

Beck, Ulrich. 1986. Risikogesellschaft. Aufdem Weg in eine andere Moderne. Frankfurt am Main: Suhrkamp.

Beck, Ulrich (Hrsg.). 1994. Riskante Freiheiten: Individualisierung in modernen Gesellschaften. 1. Aufl. Erstaus. Frankfurt am Main: Suhrkamp.

Beck, Ulrich. 2007. Weltrisikogesellschaft. Aufder Suche nach der verlorenen Sicherheit. Frankfurt am Main: Suhrkamp.

Bell, Daniel. 1973. The Coming of post-industrial society: a venture in social forecasting. New York: Basic Books.

Bell, Daniel. 1975. Die nachindustrielle Gesellschaft. Frankfurt am Main: Campus Verlag.

Böhme, Gernot / Stehr Nico (eds.).1986: The Knodlege Society: the growing impact of scientific knowledge on social relations. Dordrecht: Reidel.

Birnbacher, Dieter. 1988. Verantwortung für zukünftige Generationen. Stuttgart: Reclam.

Binde, Jerome. 2007. Die Zukunft der Werte. Dialoge über das 21 Jahrhundert. Paris: Suhrkamp Verlag.

Brenner, Andreas. 1996. Ökologie-Ethik. Leipzig: Reklam Verlag.

Castells, Manuel. 1996. The rise of the Network Society. 1. Publ., Cambridge, Mass: Blackwell.

Descartes, Rene. 1986. Meditationen über die Philosophie / Meditationes de Prima Philosophia. Ditzinger: Reclam.

Drucker, P.F. 1994a. "The Age of Social Transformation". In : The Atlantic Monthly 273 (11): 53-80.

Drucker, P.F. 1994b. Knowledge Work and Knowledge Society. The Social Transformations of this Centry. L. Godkin Lecture at Harvard University's John F. Kennedy School of Governmernt (May 4, 1994) See http://www.ksg.harvard. edu/ifactory/ksgpress/www/ksg_newa/transcripts/drucklec

Freud, Sigmund. 1940. Gesammelte Werke. (Vorlesungen zur Einführung in die Psychoanalyse 1916-17) Frankfurt a.M.: Fischer. 
Gross, Peter. 1994. Die Multioptionsgesellschaft. 1. Auflage., Erstausgabe, Frankfurt am Main: Suhrkamp.

Horx, Matthias. 2002. Die acht sphären der Zukunft: Ein Wegweiser in die Kultur des 21. Jahrhunderts. 4. Auflage. Wien, München: Signum Verlag.

Huber, Wolfgang. 2013. Ethik, Die Grundfragen unseres Lebens von der Geburt bis zum Tod. München: C.H.Beck.

Höffe, Otfried. 1993. Moral als Preis der Moderne: ein Versuch über Wissenschaft, Technik und Umwelt. Frankfurt am Main: Suhrkamp.

Jonas, Hans. 1979. Das Prinzip Verantwortung. Versuch einer Ethik für die technologische Zivilisation. Frankfurt am Main:Suhrkamp. 1979, S. 36

Jonas, Hans.1985. Technik, Medizin und Ethik. Zur Praxis des Prinzips Verantwortung. Frankfurt am Main: Insel Verlag.

Jonas, Hans. 1987. Technik, Medizin und Ethik. Zur Praxis des Prinzips Verantwortung. Frankfurt am Main: Suhrkamp.

Jonas Hans und Mieth Dieter. 1983. Was für morgen lebenswichtig ist. Unentdeckte Zukunftswerte. Freiburg, Basel, Wien: Herder.

Knorr-Cetina, Karin. 1989. Die Fabrication von Erkenntnis. Wissenschftl. Sonderausg. 1. Aufl. Frankfurt am Main: Suhrkamp.

Kreibich, Rolf. 1986. Die Wissensgesellschaft: von Galilei zur High-TechRevolution. 2. Aufl. Frankfurt am Main: Suhrkamp.

Müller, Wolfgang Erich. 1988. Der Begriff der Verantwortung bei Jonas. Frankfurt am Main: Athenäum Verlag GmbH.

Opaschowski,W. Horst. 2013. Deutschland 2030. Aktualisierte Neuausgabe, Gütersloh: Gütersloher Verlagshaus.

Picht, Georg. 1969. Wahrheit, Vernunft und Verantwortung. Philosophische Studien. Stuttgart: Klett.

Picht, Georg. 1979. "Zum Begriff des Maßes". In: Humanökologie und Frieden, hrsg. v. Eisenbart, Constanze, 418-426, Stuttgart: Klett-Cotta.

Pinquart Martin und Rainer K. Silbereisen. 2007. Sozialer Wandel. In: Hasselhorn Markus und Wolfgang Schneider: Handbuch der Entwicklungspsychologie. Göttingen u.a.: Hogrefe Verlag.

Schärli-Corradini, Beatrice M. 1992. Bedrohter Morgen : Anregungen des Kindes zu einem kreativen Umgang mit Lebenskrise und Umweltkrise. Zürich: Zentralstelle der Studentenschaft.

Schmiede, Rudi. 2004. Information, Wissen und Gesellschaft. In: Gamm u.a. Die Gesellschaft im 21. Jahrhundert. Perspektiven auf Arbeit, Leben, Politik. Frankfurt, New York: Campus Verlag.

Schmid, Wilhelm. 1993. Was geht uns Deutschland an? 1. Aufl., Frankfurt am Main: Suhrkamp.

Schmid, Wilhelm. 1998. Philosophie der Lebenskunst. Eine Grundlegung. Frankfurt am Main: Suhrkamp.

Schmid, Wilhelm. 2004. Mit sich selbst befreundet sein. Von der Lebenskunst im Umgang mit sich selbst. Frankfurt a.M.: Suhrkamp. 
Schulze, Gerhard. 1992. Die Erlebnisgesellschaft. Kultursoziologie der Gegenwart. Frankfurt am Main: Campus Verlag.

Steinmüller Karlheinz. 2000. Zukunftsforschung in Europa. Ein Abriß der Geschichte. In: Steinmüller, Karlheinz u.a.(Hrsg.): Zukunftsforschung in Europa. Ergebnisse und Perspektiven. 1. Aufl., Baden-Baden: Nomos Verlagsgesellschaft.

Stehr, Nico. 1994. Arbeit, Eigentum und Wissen: Zur Theorie von Wissensgesellschaften. Frankfurt am Main: Suhrkamp.

Stehr, Nico und Marian Adolf. 2015. Ist Wissen Macht? Erkenntnisse über Wissen. 1. Aufl. Weilerwist: Velbrück Wissenschaft.

Stückelberger, bChristoph. 1997. Umwelt und Entwicklung: eine sozialethische Orientierung. Stuttgart, Berlin, Köln: Kohlhammer.

Ulfig, Alexander. 2003. Die Überwindung des Individualismus. Versuch einer Lebensorientierung. Essen: Die Blaue Eule Verlag.

Wittgens, Matthias. 1999. "Wissensgesellschaft und gesellschaftliche Wissensproduktion." In: Grenzenlose Gesellschaft? Verhandlungen des 29. Kongresses der Deutschen Gesellschaft fütr Soziologie, des 16. Kongresses des Österreichischen Gesellschaft für Soziologie, des 11. Kongresses der Schweizerischen Gesellschaft für Soziologie in Freiburg i, Br. 1998. Teil I., hrsg. v. Claudia Honneger et.al., 433-447, Opladen: Leske+Budrich. 